Prepared for the U.S. Department of Energy under Contract DE-AC05-76RL01830

\title{
Guidelines for Estimating Unmetered Landscaping Water Use
}

KL McMordie Stoughton

July 2010

Pacific Northwest

NATIONAL LABORATORY

Proudly Operated by Battelle Since 1965 


\title{
DISCLAIMER
}

This report was prepared as an account of work sponsored by an agency of the United States Government. Neither the United States Government nor any agency thereof, nor Battelle Memorial Institute, nor any of their employees, makes any warranty, express or implied, or assumes any legal liability or responsibility for the accuracy, completeness, or usefulness of any information, apparatus, product, or process disclosed, or represents that its use would not infringe privately owned rights. Reference herein to any specific commercial product, process, or service by trade name, trademark, manufacturer, or otherwise does not necessarily constitute or imply its endorsement, recommendation, or favoring by the United States Government or any agency thereof, or Battelle Memorial Institute. The views and opinions of authors expressed herein do not necessarily state or reflect those of the United States Government or any agency thereof.

\author{
PACIFIC NORTHWEST NATIONAL LABORATORY \\ operated by \\ BATTELLE \\ for the \\ UNITED STATES DEPARTMENT OF ENERGY \\ under Contract DE-AC05-76RL01830 \\ Printed in the United States of America \\ Available to DOE and DOE contractors from the \\ Office of Scientific and Technical Information, \\ P.O. Box 62, Oak Ridge, TN 37831-0062; \\ ph: (865) 576-8401 \\ fax: (865) 576-5728 \\ email: reports@adonis.osti.gov

\begin{abstract}
Available to the public from the National Technical Information Service, U.S. Department of Commerce, 5285 Port Royal Rd., Springfield, VA 22161 ph: (800) 553-6847 fax: (703) 605-6900 email: orders@ntis.fedworld.gov

online ordering: http://www.ntis.gov/ordering.htm
\end{abstract}

This document was printed on recycled paper. 
PNNL-19498

\section{Guidelines for Estimating Unmetered Landscaping Water Use}

KL McMordie Stoughton

July 2010

Prepared for

U.S. Department of Energy

Federal Energy Management Program

Under Contract DE-AC05-76RL01830

Pacific Northwest National Laboratory

Richland, Washington 99352 



\section{Summary}

Executive Order 13514 requires Federal agencies to develop a baseline for industrial, landscaping, and agricultural water use in fiscal year 2010. Measuring actual water use through flow meters is the best method to develop this baseline. But there are instances where Federal sites do not meter these applications, so developing a baseline will be problematic. Therefore the intent of this document is to assist Federal agencies in the baseline development by providing a methodology to calculate unmetered sources of landscaping water use utilizing engineering estimates.

The document lays-out step by step instructions to estimate landscaping water using two alternative approaches: evapotranspiration method and irrigation audit method. The evapotranspiration method option calculates the amount of water needed to maintain a healthy turf or landscaped area for a given location based on the amount of water transpired and evaporated from the plants. The evapotranspiration method offers a relatively easy "one-stop-shop" for Federal agencies to develop an initial estimate of annual landscape water use. The document presents annual irrigation factors for 36 cities across the U.S. that represents the gallons of irrigation required per square foot for distinct landscape types. By following the steps outlined in the document, the reader can choose a location that is a close match their location and landscape type to provide a rough estimate of annual irrigation needs without the need to research specific data on their site.

The second option presented in the document is the irrigation audit method, which is the physical measurement of water applied to landscaped areas through irrigation equipment. Steps to perform an irrigation audit are outlined in the document. An irrigation audit requires some knowledge on the specific procedures to accurately estimate how much water is being consumed by the irrigation equipment. 


\section{Acknowledgments}

This document was prepared by the Pacific Northwest National Laboratory (PNNL) on behalf of the Federal Energy Management Program. PNNL would like to thank the Federal Water Working Group of the Interagency Energy Management Task Force, which provided initial direction and later review of the supplemental guidance.

Representatives of the working group include the following individuals:

Dan Amon - Environmental Protection Agency

Andy Crigler - Department of Defense - Office of the Secretary of Defense

William Eng - Department of Defense - Army

Bucky Green - Environmental Protection Agency

Michael Green - National Aeronautical Space Administration

Mary Heying - Department of Interior

Sam Higuchi - National Aeronautical Space Administration

Charles Johnson - Department of Agriculture

Dexter Johnson - Environmental Protection Agency

Regina Larrabee - Veterans Affairs

William Lintner - Department of Energy, Chairman

Jose Maniwang - Department of Justice

Daniel Magro - Department of Defense - Navy

Don Mauritz - Lawrence Berkeley National Laboratory

Sandy Morgan - Department of Agriculture

Tara O'Hare - Environmental Protection Agency

John Park - Veterans Affairs

Larry Pierce - Department of Housing and Urban Development

Robert Scinta - Department of Commerce

Justin Spenillo - Environmental Protection Agency

Stephanie Tanner - Environmental Protection Agency

Wayne Thalasinos - National Aeronautical Space Administration

Chris Tindal - Department of Defense - Navy

Chau Tran - Department of Justice

Cynthia Vallina - Office of Management and Budget

David Zimmerman - Tennessee Valley Authority

The following people also provided technical and production assistance:

Sue Arey - Pacific Northwest National Laboratory

Brian Boyd - Pacific Northwest National Laboratory

Elisabeth Giever - Pacific Northwest National Laboratory

Peter Mayer - Aquacraft Inc.

Bill Sandusky - Pacific Northwest National Laboratory 


\section{Contents}

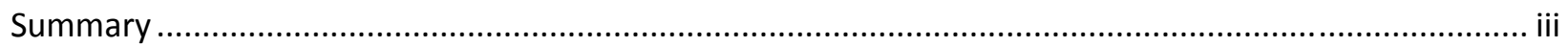

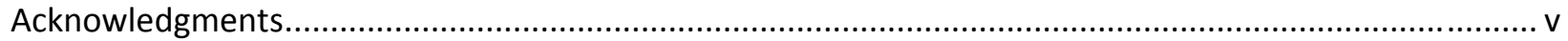

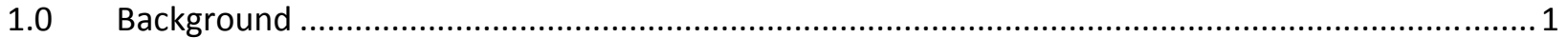

2.0 Option 1: Estimating Landscaping Water Use Using the Evapotranspiration Method.................... 3

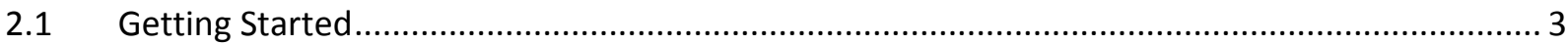

$2.2 \quad$ Find the Best Match to your Location ................................................................................... 4

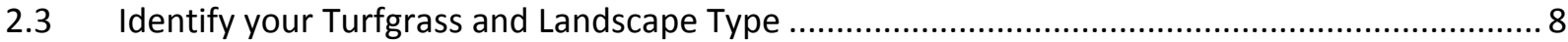

2.4 Estimate Square Footage of the Irrigated Area ....................................................................... 10

2.5 Select the Annual Irrigation Factor ......................................................................................... 11

2.6 Determine your Irrigation System Efficiency …................................................................ 16

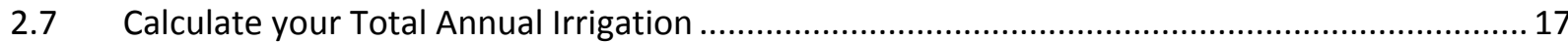

3.0 Option 2: Estimating Landscaping Water Use Using the Irrigation Audit Method ........................2 21

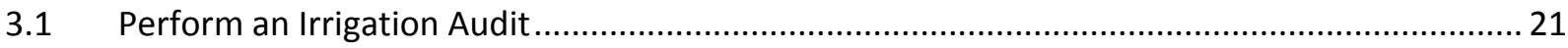

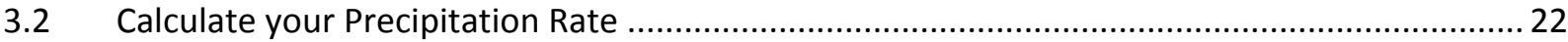

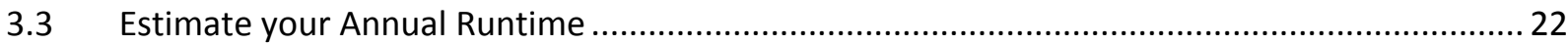

3.4 Estimate Square Footage of the Irrigated Area …............................................................... 22

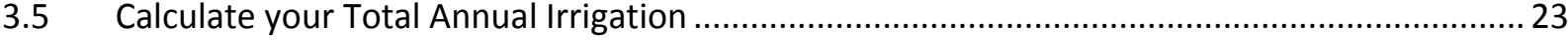

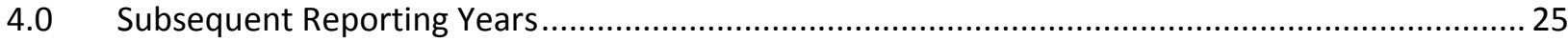

5.0 Glossary

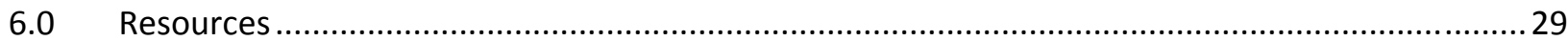

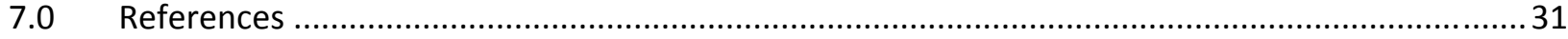

Appendix -- Calculations for the Annual Irrigation Factor Tables ..................................................... A-1 


\section{Figures}

Figure 1 - Climate Zones of the United States and Puerto Rico ........................................................... 5

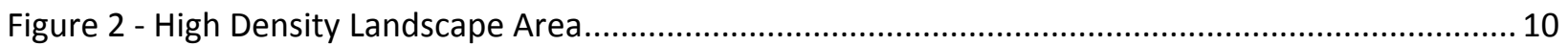

\section{Tables}

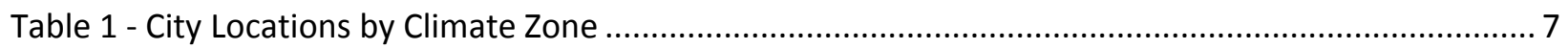

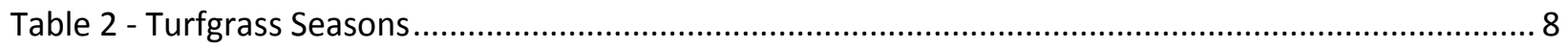

Table 3 - Annual Irrigation Factor -- Turfgrass (gal/sqft/year) .......................................................... 12

Table 4 - Annual Irrigation Factor -- Landscaped Areas with High Water Requirements (gal/sqft/yr) ...... 13

Table 5 - Annual Irrigation Factor -- Landscaped Areas with Moderate Water Requirements

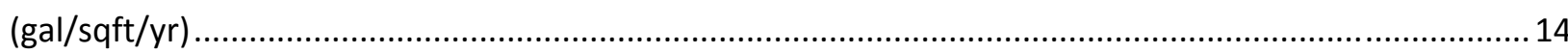

Table 6 - Annual Irrigation Factor -- Landscaped Areas with Low Water Requirements (gal/sqft/yr) ....... 15 


\subsection{Background}

Executive Order 13514, Federal Leadership in Environmental, Energy, and Economic Performance, was signed on October 5, 2009 by President Obama. EO 13514 has water provisions that require Federal agencies to improve water use efficiency and management as follows:

1. Reduce potable water consumption intensity by $2 \%$ annually through fiscal year (FY) 2020 , or $26 \%$ by the end of fiscal year 2020, relative to a FY 2007 baseline.

2. Reduce agency industrial, landscaping, and agricultural water consumption $2 \%$ annually, or $20 \%$ by the end of fiscal year 2020, relative to a FY 2010 baseline.

The second provision listed above requires that Federal agencies develop a baseline for industrial, landscaping, and agricultural water use so that all efficiency efforts can be judged against this baseline. Each Federal site must develop a baseline for these industrial, landscaping, and agricultural uses and report the total FY 2010 consumption to their respective agency. Measuring actual water use through flow meters is the best method to develop the FY 2010 baseline. But there are instances where Federal sites do not meter these applications, so developing a baseline will be problematic. If permanent metering is not practical, then a temporary flow meter offers a sound solution. Temporary ultra-sonic flow meters can be installed to the outside of a pipe and do not require a disruption of the process. If large landscapes pull irrigation water from an on-site well that contain reliable pumping records, water use can be estimated by taking the pump flow rate at the given well depth multiplied by the annual runtime.

If these metering options are not applicable or practical and the landscaping water source is not from an on-site well with adequate pumping records, then an engineering estimate must be used to estimate annual water use. Therefore, the intent of this document is to assist Federal agencies in estimating unmetered sources of landscaping water use utilizing engineering estimates ${ }^{1}$. Two approaches are covered in this document:

1. Evapotranspiration Method - estimate of supplemental water requirements based on the amount of water transpired and evaporated from the plants for different locations across the U.S.

2. Irrigation Audit Method - physical measurement of water applied to landscaped areas through irrigation equipment

The evapotranspiration (ET) method provided in this document serves as an initial starting place for estimating landscaping water use baseline whereas the irrigation audit offers a method of spot measuring actual landscape water use. It should be noted that an irrigation audit requires knowledge on how to perform an audit and requires the purchase of some minor equipment. On the other hand, the ET method does not require training or purchase of equipment but does require some basic knowledge of the landscape and the use of specific calculations provided in this document. This

\footnotetext{
${ }^{1}$ Note, the Federal Energy Management Program has produced a companion document that provides a methodology on how to estimate unmetered industrial processes.
} 
document focuses on the ET method because it offers a relatively easy "one-stop-shop" for Federal agencies to develop an initial estimate of annual landscape water use for the FY 2010 baseline. The irrigation audit method is also discussed so that both options can be considered. Note several assumptions are required to use the ET method in this document; therefore the estimated landscape water use can have a fairly wide range of possible values. 


\subsection{Option 1: Estimating Landscaping Water Use Using the Evapotranspiration Method}

The evapotranspiration (ET) method calculates the amount of water needed to maintain a healthy turf or landscaped area for a given location based on the water requirements of the type of plants, specific conditions of the site, and precipitation received by the site. ET represents the loss of water from the Earth's surface through the combined processes of evaporation (from soil and plant surfaces) and plant transpiration.

\subsection{Getting Started}

This document describes how to estimate annual supplemental irrigation requirements for:

- Cool and warm season turfgrasses

- Low water consuming landscaped area

- Moderate water consuming landscaped areas

- High water consuming landscaped areas

Annual Irrigation Factor: This document provides annual irrigation factors for 36 cities across the U.S. that represents the gallons of irrigation required per square foot for distinct landscape and turf types in corresponding locations (shown in Tables 3 through 6 of this document). ET and precipitation data was acquired for all 36 U.S. locations to estimate these annual irrigation factors. Multiplying the appropriate factor by the square footage of your landscape or turfgrass area and dividing this value by the system efficiency will provide you an estimate of the annual irrigation requirements for a given location. Through the process described in this document, you can estimate your irrigation requirements by choosing a U.S. location that closely matches your area. This will give you an initial estimate for your landscaping water use baseline without the need to research and investigate your local ET and precipitation data*.

To use the process laid out in the document, you will need to perform six key steps to estimate your total annual landscaping water use:

1. Find the best match to your location

* The Appendix provides detailed information on how the annual irrigation factors were developed. If you want to calculate a more precise annual irrigation factor instead of choosing one from the 36 cities that are provided in Tables 3 through 6, collect local $E T$ and precipitation data on your location for FY 2010 and follow the process in the Appendix.

2. Identify your turf and landscape area type

3. Estimate your square footage of turf and landscaped areas

4. Select the appropriate annual irrigation factor from the tables in the document

5. Determine the irrigation system efficiency

6. Calculate your total annual irrigation 
This information is utilized to estimate the total annual landscape water use by using the following formula:

$$
\begin{aligned}
& \text { Annual Landscape Water Use (gallons per year) } \\
& \qquad=\frac{\text { Annual Irrigation Factor }\left(\frac{g a l}{\text { sqft }-y r}\right) \times \text { Irrigation Area (sqft) }}{\text { Irrigation System Efficiency }}
\end{aligned}
$$

These steps are outlined in the flowchart below:

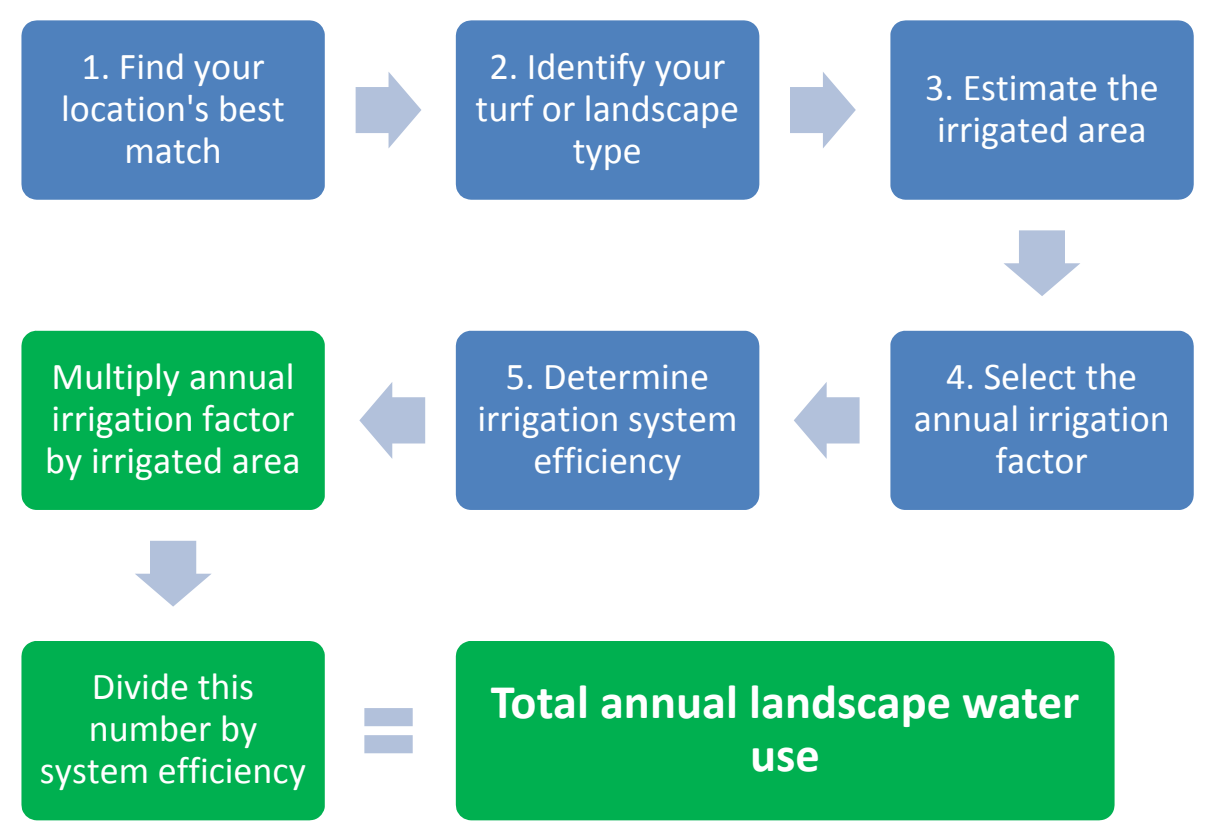

The remainder of this section takes you through these steps.

\subsection{Find the Best Match to your Location}

The first step in this process is to pick a city in Figure 1 that best matches your location. Figure 1 shows general climate zones in the U.S. with several cities identified in each zone [ZenTech 2010]. This document provides the annual irrigation needs for different landscape types for each of these locations.

\section{It is very important to pick the best match to your location so that the irrigation estimate is as}

accurate as possible. To assist with this, a listing of the cities with associated climate zones, zip codes, peak reference evapotranspiration ( $\mathrm{ET}_{\mathrm{o}}$ ) and rainfall values are provided in Table $1^{2}$. The peak $\mathrm{ET}_{\mathrm{o}}$ (referring to the month with the highest ET requirement) and rainfall data can be used to help identify the best match for your location's climate if you are unsure which city is most appropriate. First, go to

\footnotetext{
${ }^{2} \mathrm{ET}_{\mathrm{O}}$ refers to the reference evapotranspiration. More information is provided on $\mathrm{ET}_{\mathrm{O}}$ in the Glossary and Appendix of this document.
} 
the U.S. Environmental Protection Agency (EPA) WaterSense Program "Water Budget Data Finder" website: http://www.epa.gov/watersense/nhspecs/wb data finder.html Enter the zip code of your location in the box provided in the website. Note the peak $\mathrm{ET}_{\mathrm{o}}$ and rainfall value of your location. Then find a few locations in Table 1 that have similar $\mathrm{ET}_{\mathrm{o}}$ and rainfall values and pick the city that best matches this information and is in a similar climate zone. By doing this, you are choosing the city that has similar irrigation requirements to your location. See an example of this process at the end of this section.

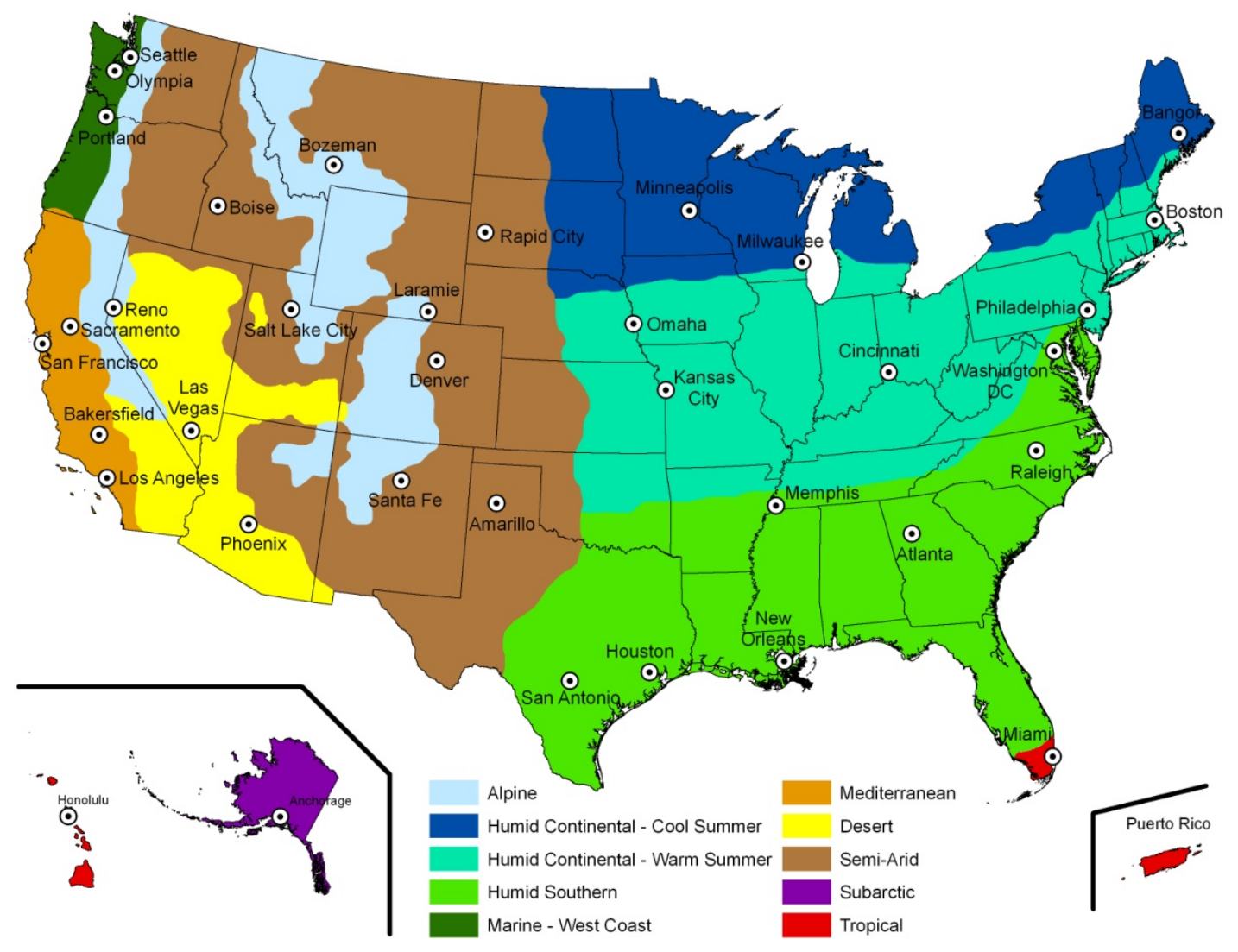

Figure 1 - Climate Zones of the United States and Puerto Rico 
The Climate zones of the U.S. depicted in this map are:

- Alpine: high mountain regions of the Rocky Mountains, Sierra Nevada, and Cascade Mountain ranges

- Desert: regions of the U.S. that receive very little precipitation including southern Arizona, south eastern California, southern Utah, and Nevada

- Humid Continental (cool summer): northeastern areas of the U.S. that typically have cooler summers and harsh winters such as up-state New York, Vermont, Minnesota, and Wisconsin

- Humid Continental (warm summer): Midwestern and northeastern areas of the U.S. with hotter summers and milder winters such as Ohio, Indiana, and Pennsylvania

- Humid Southern: hot humid regions of the southern U.S. such as Mississippi, middle and eastern Texas, Georgia, and Florida

- Mediterranean: western regions of California

- Marine - West Coast: coastal regions of Oregon and Washington

- Semi-arid: regions of the U.S. which are characterized by grasslands or sparsely treed areas that have relatively low levels of precipitation such as western Kansas, New Mexico, Idaho, and eastern Wyoming and eastern Colorado

- Subarctic: Very cold regions, namely Alaska

- Tropical: regions in the U.S. that are hot and humid and have no significant seasonal changes including the southern tip of Florida, Hawaii, and Puerto Rico 
Table 1 - City Locations by Climate Zone [ZenTech 2010]

\begin{tabular}{|c|c|c|c|c|c|}
\hline Climate Zone & City & State & Zip Code & $\begin{array}{c}\text { Peak ET。 } \\
\text { (in/mo) }\end{array}$ & $\begin{array}{l}\text { Peak Rainfall } \\
\text { (in/mo) }\end{array}$ \\
\hline Alpine & Bozeman & MT & 59715 & 7.37 & 1.44 \\
\hline Alpine & Laramie & WY & 82051 & 7.44 & 1.33 \\
\hline Alpine & Santa Fe & NM & 87501 & 7.75 & 1.16 \\
\hline Desert & Bakersfield & $\mathrm{CA}$ & 93301 & 10.39 & 0.00 \\
\hline Desert & Las Vegas & NV & 89044 & 13.03 & 0.03 \\
\hline Desert & Phoenix & $A Z$ & 85003 & 13.40 & 0.02 \\
\hline Desert & Reno & NV & 89501 & 8.92 & 0.13 \\
\hline Humid Continental - Cool Summer & Bangor & $\mathrm{ME}$ & 04401 & 4.80 & 3.03 \\
\hline Humid Continental - Cool Summer & Milwaukee & WI & 53202 & 6.08 & 3.11 \\
\hline Humid Continental - Cool Summer & Minneapolis & $\mathrm{MN}$ & 55401 & 6.85 & 3.41 \\
\hline Humid Continental - Warm Summer & Boston & MA & 02108 & 6.18 & 2.66 \\
\hline Humid Continental - Warm Summer & Cincinnati & $\mathrm{OH}$ & 45202 & 6.23 & 3.34 \\
\hline Humid Continental - Warm Summer & Kansas City & $\mathrm{MO}$ & 64101 & 7.43 & 3.47 \\
\hline Humid Continental - Warm Summer & Omaha & NE & 68102 & 7.15 & 3.14 \\
\hline Humid Continental - Warm Summer & Philadelphia & PA & 19102 & 6.25 & 3.43 \\
\hline Humid Southern & Atlanta & GA & 30303 & 6.48 & 3.29 \\
\hline Humid Southern & Houston & $\mathrm{TX}$ & 77002 & 6.91 & 3.24 \\
\hline Humid Southern & Memphis & TN & 38103 & 7.38 & 3.17 \\
\hline Humid Southern & New Orleans & LA & 70116 & 6.13 & 4.08 \\
\hline Humid Southern & Raleigh & NC & 27601 & 6.03 & 3.53 \\
\hline Humid Southern & San Antonio & TX & 78205 & 8.42 & 0.87 \\
\hline Humid Southern & Washington & DC & 20004 & 6.46 & 2.99 \\
\hline Marine - West Coast & Olympia & WA & 98501 & 5.14 & 0.70 \\
\hline Marine - West Coast & Portland & OR & 97086 & 6.20 & 0.58 \\
\hline Marine - West Coast & Seattle & WA & 98101 & 5.44 & 0.65 \\
\hline Mediterranean & Los Angeles & $\mathrm{CA}$ & 90001 & 6.59 & 0.00 \\
\hline Mediterranean & Sacramento & $\mathrm{CA}$ & 95814 & 9.47 & 0.00 \\
\hline Mediterranean & San Francisco & CA & 94102 & 5.24 & 0.04 \\
\hline Semi-arid & Amarillo & TX & 79107 & 9.64 & 2.33 \\
\hline Semi-arid & Boise & ID & 83601 & 7.76 & 0.45 \\
\hline Semi-arid & Denver & $\mathrm{CO}$ & 80002 & 8.25 & 1.78 \\
\hline Semi-arid & Rapid City & SD & 57701 & 7.86 & 2.01 \\
\hline Semi-arid & Salt Lake City & UT & 84101 & 10.13 & 0.57 \\
\hline Subarctic & Anchorage & AK & 99501 & 4.09 & 1.03 \\
\hline Tropical & Honolulu & $\mathrm{HI}$ & 96853 & 7.44 & 5.87 \\
\hline Tropical & Miami & $\mathrm{FL}$ & 33010 & 6.65 & 2.16 \\
\hline
\end{tabular}




\subsection{Identify your Turfgrass and Landscape Type}

Next, you need to identify which areas are irrigated at your facility and if these areas are predominantly turfgrass or landscaped plants. For example, recreational and athletic fields are typically considered turfgrass area. Areas with a mixture of plants such as trees, shrubs, and flowerbeds are considered landscaped areas.

You need to identify the type of turfgrass and landscaped areas at your location. The next two sections help to direct you on how to do this.

\section{Turfgrass Type}

In general, there are two types of turfgrass - cool and warm season. Cool season grasses thrive in cooler climates and generally require more water than warm season grass to thrive. Warm season grasses are better suited for hot summers and are generally more drought tolerant. You'll need to know which type of grass you irrigate. Your ground maintenance personnel should be able to identify which type of grass you have at your location. Table 2 lists common species of grass and their associated season. (See the section on Turfgrass Evapotranspiration in the Appendix to learn more about turfgrass water requirements.)

Table 2 - Turfgrass Seasons [California Department of Water Resources 2000] [University of Florida 2009]

\begin{tabular}{|l|c|}
\hline Turfgrass type & Season Type \\
\hline annual bluegrass & cool \\
\hline annual ryegrass & cool \\
\hline Bermuda grass & warm \\
\hline buffalo grass & warm \\
\hline colonial bentgrass & cool \\
\hline creeping bentgrass & cool \\
\hline hard fescue & cool \\
\hline highland bentgrass & cool \\
\hline Kentucky bluegrass & cool \\
\hline kikuyugrass & warm \\
\hline meadow fescue & cool \\
\hline perennial ryegrass & cool \\
\hline red fescue & cool \\
\hline rough-stalked & cool \\
\hline seashore paspalum & warm \\
\hline St. Augustinegrass & warm \\
\hline tall fescue & cool \\
\hline zoysiagrass & warm \\
\hline
\end{tabular}




\section{Landscape Type}

For landscape areas that are not exclusively turfgrass such as sites with trees, shrubs, and flowerbeds, there are three parameters that designate the amount of water necessary for plants to thrive:

1. Water requirements of the plant species (low, moderate, or high)

2. Density of plantings (low, average, or high)

3. Type of microclimate of the landscape (protected, open, or intense exposure)

These parameters are described below to help you identify which type you have at your facility.

\section{Landscape Water Requirements}

Supplemental water requirements for landscape plants vary across the U.S. You need to determine the relative amount of irrigation that is required for your landscape. The ranges of watering requirements used in this document are low, moderate, or high water requirements. Keep in mind that the water requirements for your landscape are specific to your area. Plants that require low amounts of water are native or well adapted plants to a particular area (which is a good strategy to limit supplemental irrigation requirements). If your landscape does not include species that are native or drought tolerant in your area, then they likely are moderate to high water consuming plants. For example, a native tree to Tennessee, (e.g. White Oak), will require very little supplemental water in its home state, but will require large amounts of irrigation in an arid state such as Nevada to thrive.

To identify the level of supplemental water required for the plants in your landscape, contact your ground maintenance department. If you cannot get information on the general water requirements of your landscaped areas from staff on site, then you'll need to do some investigating. Local organizations such as a cooperative extension office of a local university may be a good starting place. The cooperative extension office in your area will likely have water requirements of specific plants. The U.S. Department of Agriculture has a website that identifies local cooperative extension offices across the country at: http://www.csrees.usda.gov/Extension/

Because each cooperative extension office will have a different set of information on their website, you'll likely save time by calling the office to talk to staff at the office about getting resources on water requirements rather than performing a web search. But before you call, you'll need to know the general types of plants that are in your landscaped areas. Remember, you are trying to determine if your landscape area has low, moderate, or high water requirements for your location. 


\section{Planting Density}

The second parameter you must identify to designate your landscape type is the number of plants in the area relative to the total area. In other words, how compactly planted is the landscape? Here are the three density levels to choose from:

- Low density: immature and sparsely planted landscape

- Average density: full coverage but predominantly one vegetation type

- High density: landscape with mixture of plant types with full coverage such as trees, flowers, and shrubs (as shown in Figure 2)

\section{Microclimate}

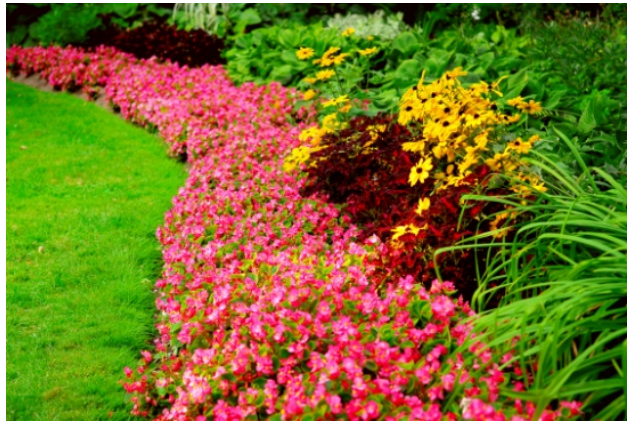

Figure 2 - High Density Landscape Area

The last parameter you need to identify for determining your landscaped area type is the microclimate. Microclimate takes into consideration the environment in which the landscape is planted such as a shady or sunny location. Here are the three designated types of microclimates to choose from for your landscape:

- Protected: areas shaded from sunlight and protected from wind and heat gain such as a landscape on a north side of a building or with a protective wind barrier

- Open: areas that are in an open flat field such as a park or athletic field

- Intense Exposure: areas exposed to high heat gain or windy conditions such as a landscape with southern exposure or near highly reflective surface like a street median

\subsection{Estimate Square Footage of the Irrigated Area}

The next thing you need to identify to estimate the annual irrigation use is the total square footage of your landscape or turf area. It is important to carefully calculate this number. Some sites may have detailed drawings and plans that will indicate total area of landscape and turf. If you don't have this level of information, there are other techniques that can be used. For example, if you have the total lot size of your facility, subtract the footprint of any structure on the lot as well as any hardscape such as parking lots and sidewalks from the total lot area to determine the net area of landscaped space. Make sure that your units are consistent and that your final area is in square feet. Also, be certain that you are including only irrigated areas. Some locations may have a mixture of irrigated and non-irrigated sections.

There are online sources that can help identify total lot size. An example is a tool called Draft Logic Google ${ }^{T M}$ Maps Area Calculator Tool. This online resource allows the user to hone in on a specific location on Google ${ }^{\mathrm{TM}}$ Maps and then define the area and automatically provides the total square feet of 
area of the defined lot. Find this tool at: http://www.daftlogic.com/projects-google-maps-areacalculator-tool.htm

Once you enter this website, switch the map to "satellite" mode by selecting it from the drop down list in the right hand corner. Then enter the zip code of your location. Zoom in on your location close enough so that you can see all the distinct points of your landscape area. Then select each major point of your landscape area. Lines will pop up as you select points that define the area you are selecting. The total area in square feet of your landscape will appear at the bottom of the map.

\subsection{Select the Annual Irrigation Factor}

Next, select the appropriate annual irrigation factor. The annual irrigation factor is the amount of annual supplemental water required to maintain healthy turf or landscaped area. Below you'll find a series of four tables that provide this factor for cool and warm season turfgrasses as well as low, moderate, and high water consuming landscaped areas. The annual irrigation factor takes into account the typical growing season for each location as well the amount of effective precipitation received by the plants for the specific location. (See more details on these terms and methodology in the Glossary and Appendix.)

Here is a description of the tables provided and direction on how to use them:

- Turfgrasses: Table 3 shows the annual irrigation factor for both cool season and warm season turf types. Identify the season of your turf and find the nearest location. Note the annual irrigation factor.

- Landscaped Areas: Tables 4 through 6 show landscape types for high, moderate, and low water consuming plants. First, find the table that best suits the plants' water requirements (high, moderate, or low). Then, choose the landscape type that best suits your area in terms of density and microclimate. Note the annual irrigation factor for the nearest location. Here are the types of landscapes that are included in each table:

o Low density and protected microclimate

o Average density and open microclimate

o High density and intense exposure microclimate

Your landscape may not be a perfect match to the scenarios in the table. For example, you may have low density plantings but intense exposure in your landscape. If this is the case, consider choosing two scenarios that closely meet your landscape type, and then select a factor that is in between this range to determine your annual water use. An example of this process is provided at the end of the section.

Note, if the annual irrigation factor in the table is zero, this means that there is typically no irrigation requirement for this type of landscape for the particular location because the area receives enough precipitation to meet watering requirements for the specific landscape type. 
Table 3 - Annual Irrigation Factor -- Turfgrass (gal/sqft/year)

\begin{tabular}{|c|c|c|c|c|}
\hline Climate Zone & City & State & $\begin{array}{c}\text { cool season } \\
\text { turf }\end{array}$ & $\begin{array}{c}\text { warm } \\
\text { season turf }\end{array}$ \\
\hline Alpine & Bozeman & MT & 8.92 & 4.61 \\
\hline Alpine & Laramie & WY & 11.62 & 8.62 \\
\hline Alpine & Santa Fe & NM & 12.67 & 7.77 \\
\hline Desert & Bakersfield & $\mathrm{CA}$ & 30.76 & 22.28 \\
\hline Desert & Las Vegas & NV & 44.13 & 31.85 \\
\hline Desert & Phoenix & $A Z$ & 44.96 & 32.16 \\
\hline Desert & Reno & NV & 20.22 & 14.78 \\
\hline Humid Continental - Cool Summer & Bangor & ME & 0.85 & 0.05 \\
\hline Humid Continental - Cool Summer & Milwaukee & WI & 3.63 & 0.73 \\
\hline Humid Continental - Cool Summer & Minneapolis & MN & 5.30 & 0.73 \\
\hline Humid Continental - Warm Summer & Boston & MA & 4.63 & 0.97 \\
\hline Humid Continental - Warm Summer & Cincinnati & $\mathrm{OH}$ & 3.66 & 0.47 \\
\hline Humid Continental - Warm Summer & Kansas City & MO & 4.31 & 0.81 \\
\hline Humid Continental - Warm Summer & Omaha & NE & 5.67 & 1.75 \\
\hline Humid Continental - Warm Summer & Philadelphia & PA & 3.31 & 0.37 \\
\hline Humid Southern & Atlanta & GA & 4.55 & 0.70 \\
\hline Humid Southern & Houston & $\mathrm{TX}$ & 6.50 & 1.15 \\
\hline Humid Southern & Memphis & TN & 7.35 & 3.22 \\
\hline Humid Southern & New Orleans & LA & 1.47 & 0.10 \\
\hline Humid Southern & San Antonio & $\mathrm{TX}$ & 19.37 & 10.82 \\
\hline Humid Southern & Raleigh & NC & 3.33 & 0.20 \\
\hline Humid Southern & Washington & DC & 5.20 & 0.91 \\
\hline Marine - West Coast & Olympia & WA & 6.03 & 3.28 \\
\hline Marine - West Coast & Portland & OR & 7.20 & 4.10 \\
\hline Marine - West Coast & Seattle & WA & 7.45 & 4.43 \\
\hline Mediterranean & Los Angeles & $\mathrm{CA}$ & 20.72 & 14.64 \\
\hline Mediterranean & Sacramento & $\mathrm{CA}$ & 22.86 & 17.35 \\
\hline Mediterranean & San Francisco & $\mathrm{CA}$ & 14.13 & 10.34 \\
\hline Semi-arid & Amarillo & $T X$ & 25.53 & 15.47 \\
\hline Semi-arid & Boise & ID & 13.68 & 9.41 \\
\hline Semi-arid & Denver & $\mathrm{CO}$ & 14.30 & 9.57 \\
\hline Semi-arid & Rapid City & SD & 11.98 & 6.78 \\
\hline Semi-arid & Salt Lake City & UT & 18.83 & 13.24 \\
\hline Subarctic & Anchorage & AK & 3.49 & 1.78 \\
\hline Tropical & Honolulu & $\mathrm{HI}$ & 0.34 & 0.00 \\
\hline Tropical & Miami & $\mathrm{FL}$ & 7.92 & 3.30 \\
\hline
\end{tabular}


Table 4 - Annual Irrigation Factor -- Landscaped Areas with High Water Requirements (gal/sqft/yr)

\begin{tabular}{|c|c|c|c|c|c|}
\hline Climate Zone & City & State & $\begin{array}{l}\text { low density- } \\
\text { protected } \\
\text { microclimate }\end{array}$ & $\begin{array}{c}\text { average density- } \\
\text { open } \\
\text { microclimate }\end{array}$ & $\begin{array}{l}\text { high density- } \\
\text { intense exposure }\end{array}$ \\
\hline Alpine & Bozeman & MT & 2.53 & 8.92 & 18.54 \\
\hline Alpine & Laramie & WY & 5.57 & 13.27 & 22.13 \\
\hline Alpine & Santa Fe & NM & 4.05 & 12.94 & 23.43 \\
\hline Desert & Bakersfield & $\mathrm{CA}$ & 16.02 & 30.76 & 49.79 \\
\hline Desert & Las Vegas & NV & 23.80 & 44.13 & 69.62 \\
\hline Desert & Phoenix & $A Z$ & 23.79 & 44.96 & 71.51 \\
\hline Desert & Reno & NV & 10.78 & 20.22 & 32.33 \\
\hline Humid Continental - Cool Summer & Bangor & ME & 0.00 & 0.85 & 7.16 \\
\hline Humid Continental - Cool Summer & Milwaukee & WI & 0.03 & 3.67 & 12.51 \\
\hline Humid Continental - Cool Summer & Minneapolis & MN & 0.03 & 5.57 & 14.55 \\
\hline Humid Continental - Warm Summer & Boston & MA & 0.15 & 4.63 & 13.53 \\
\hline Humid Continental - Warm Summer & Cincinnati & $\mathrm{OH}$ & 0.00 & 3.66 & 14.24 \\
\hline Humid Continental - Warm Summer & Kansas City & MO & 0.07 & 4.31 & 16.48 \\
\hline Humid Continental - Warm Summer & Omaha & NE & 0.11 & 5.96 & 17.41 \\
\hline Humid Continental - Warm Summer & Philadelphia & PA & 0.00 & 3.31 & 13.98 \\
\hline Humid Southern & Atlanta & GA & 0.03 & 4.76 & 16.58 \\
\hline Humid Southern & Houston & TX & 0.09 & 6.50 & 20.73 \\
\hline Humid Southern & Memphis & TN & 0.29 & 7.36 & 19.64 \\
\hline Humid Southern & New Orleans & LA & 0.00 & 1.47 & 13.29 \\
\hline Humid Southern & San Antonio & TX & 4.95 & 19.37 & 38.92 \\
\hline Humid Southern & Raleigh & $\mathrm{NC}$ & 0.00 & 3.33 & 14.78 \\
\hline Humid Southern & Washington & DC & 0.06 & 5.20 & 16.44 \\
\hline Marine - West Coast & Olympia & WA & 1.70 & 6.03 & 12.78 \\
\hline Marine - West Coast & Portland & OR & 2.60 & 7.28 & 15.19 \\
\hline Marine - West Coast & Seattle & WA & 2.01 & 7.45 & 14.94 \\
\hline Mediterranean & Los Angeles & $\mathrm{CA}$ & 10.59 & 20.94 & 36.62 \\
\hline Mediterranean & Sacramento & $\mathrm{CA}$ & 12.03 & 23.70 & 38.67 \\
\hline Mediterranean & $\begin{array}{l}\text { San } \\
\text { Francisco }\end{array}$ & $\mathrm{CA}$ & 7.31 & 14.73 & 24.57 \\
\hline Semi-arid & Amarillo & TX & 8.81 & 25.53 & 44.38 \\
\hline Semi-arid & Boise & ID & 5.62 & 14.19 & 23.06 \\
\hline Semi-arid & Denver & $\mathrm{CO}$ & 6.03 & 14.68 & 25.55 \\
\hline Semi-arid & Rapid City & SD & 3.90 & 11.98 & 21.94 \\
\hline Semi-arid & Salt Lake City & UT & 9.07 & 18.70 & 31.27 \\
\hline Subarctic & Anchorage & $A K$ & 0.62 & 3.49 & 7.65 \\
\hline Tropical & Honolulu & $\mathrm{HI}$ & 0.00 & 0.34 & 7.97 \\
\hline Tropical & Miami & $\mathrm{FL}$ & 0.85 & 7.92 & 25.76 \\
\hline
\end{tabular}


Table 5 - Annual Irrigation Factor -- Landscaped Areas with Moderate Water Requirements
(gal/sqft/yr)

\begin{tabular}{|c|c|c|c|c|c|}
\hline Climate Zone & City & State & $\begin{array}{l}\text { low density- } \\
\text { protected } \\
\text { microclimate }\end{array}$ & $\begin{array}{l}\text { average density- } \\
\text { open } \\
\text { microclimate }\end{array}$ & $\begin{array}{l}\text { high density- } \\
\text { intense } \\
\text { exposure }\end{array}$ \\
\hline Alpine & Bozeman & MT & 0.39 & 3.15 & 8.66 \\
\hline Alpine & Laramie & WY & 1.20 & 6.26 & 12.34 \\
\hline Alpine & Santa Fe & NM & 1.04 & 4.73 & 12.59 \\
\hline Desert & Bakersfield & $\mathrm{CA}$ & 9.17 & 17.81 & 29.57 \\
\hline Desert & Las Vegas & NV & 13.77 & 26.30 & 43.27 \\
\hline Desert & Phoenix & $A Z$ & 13.46 & 26.39 & 44.06 \\
\hline Desert & Reno & NV & 5.31 & 11.98 & 20.48 \\
\hline Humid Continental - Cool Summer & Bangor & ME & 0.00 & 0.00 & 0.79 \\
\hline Humid Continental - Cool Summer & Milwaukee & WI & 0.00 & 0.13 & 3.47 \\
\hline Humid Continental - Cool Summer & Minneapolis & MN & 0.00 & 0.11 & 4.60 \\
\hline Humid Continental - Warm Summer & Boston & MA & 0.00 & 0.37 & 4.44 \\
\hline Humid Continental - Warm Summer & Cincinnati & $\mathrm{OH}$ & 0.00 & 0.04 & 3.45 \\
\hline Humid Continental - Warm Summer & Kansas City & $\mathrm{MO}$ & 0.00 & 0.28 & 4.08 \\
\hline Humid Continental - Warm Summer & Omaha & $\mathrm{NE}$ & 0.00 & 0.42 & 5.51 \\
\hline Humid Continental - Warm Summer & Philadelphia & $\mathrm{PA}$ & 0.00 & 0.03 & 3.12 \\
\hline Humid Southern & Atlanta & GA & 0.00 & 0.11 & 4.04 \\
\hline Humid Southern & Houston & $\mathrm{TX}$ & 0.00 & 0.22 & 6.08 \\
\hline Humid Southern & Memphis & $\mathrm{TN}$ & 0.00 & 0.89 & 6.61 \\
\hline Humid Southern & New Orleans & LA & 0.00 & 0.01 & 1.36 \\
\hline Humid Southern & San Antonio & $\mathrm{TX}$ & 1.58 & 6.93 & 18.82 \\
\hline Humid Southern & Raleigh & $\mathrm{NC}$ & 0.00 & 0.02 & 2.91 \\
\hline Humid Southern & Washington & $\mathrm{DC}$ & 0.00 & 0.15 & 4.50 \\
\hline Marine - West Coast & Olympia & WA & 0.37 & 2.00 & 5.87 \\
\hline Marine - West Coast & Portland & OR & 0.67 & 3.13 & 7.09 \\
\hline Marine - West Coast & Seattle & WA & 0.46 & 2.83 & 7.25 \\
\hline Mediterranean & Los Angeles & $\mathrm{CA}$ & 5.50 & 11.75 & 20.14 \\
\hline Mediterranean & Sacramento & $\mathrm{CA}$ & 7.38 & 13.79 & 22.40 \\
\hline Mediterranean & $\begin{array}{l}\text { San } \\
\text { Francisco }\end{array}$ & $\mathrm{CA}$ & 2.73 & 8.10 & 13.84 \\
\hline Semi-arid & Amarillo & $\mathrm{TX}$ & 1.49 & 11.57 & 24.43 \\
\hline Semi-arid & Boise & ID & 2.59 & 6.90 & 13.37 \\
\hline Semi-arid & Denver & $\mathrm{CO}$ & 1.24 & 7.04 & 14.32 \\
\hline Semi-arid & Rapid City & $\mathrm{SD}$ & 0.65 & 4.59 & 11.65 \\
\hline Semi-arid & Salt Lake City & UT & 4.35 & 10.25 & 18.29 \\
\hline Subarctic & Anchorage & $\mathrm{AK}$ & 0.12 & 0.75 & 3.21 \\
\hline Tropical & Honolulu & $\mathrm{HI}$ & 0.00 & 0.00 & 0.29 \\
\hline Tropical & Miami & $\mathrm{FL}$ & 0.04 & 1.20 & 7.61 \\
\hline
\end{tabular}


Table 6 - Annual Irrigation Factor -- Landscaped Areas with Low Water Requirements (gal/sqft/yr)

\begin{tabular}{|c|c|c|c|c|c|}
\hline Climate Zone & City & State & $\begin{array}{l}\text { low density- } \\
\text { protected } \\
\text { microclimate }\end{array}$ & $\begin{array}{c}\text { average } \\
\text { density-open } \\
\text { microclimate }\end{array}$ & $\begin{array}{l}\text { high density- } \\
\text { intense } \\
\text { exposure }\end{array}$ \\
\hline Alpine & Bozeman & MT & 0.00 & 0.04 & 0.66 \\
\hline Alpine & Laramie & WY & 0.01 & 0.22 & 1.66 \\
\hline Alpine & Santa Fe & NM & 0.01 & 0.19 & 1.87 \\
\hline Desert & Bakersfield & $\mathrm{CA}$ & 2.01 & 5.64 & 11.00 \\
\hline Desert & Las Vegas & NV & 3.29 & 8.46 & 16.29 \\
\hline Desert & Phoenix & $A Z$ & 3.05 & 6.99 & 16.02 \\
\hline Desert & Reno & NV & 0.89 & 2.46 & 7.13 \\
\hline Humid Continental - Cool Summer & Bangor & $\mathrm{ME}$ & 0.00 & 0.00 & 0.00 \\
\hline Humid Continental - Cool Summer & Milwaukee & WI & 0.00 & 0.00 & 0.00 \\
\hline Humid Continental - Cool Summer & Minneapolis & $\mathrm{MN}$ & 0.00 & 0.00 & 0.00 \\
\hline Humid Continental - Warm Summer & Boston & MA & 0.00 & 0.00 & 0.00 \\
\hline Humid Continental - Warm Summer & Cincinnati & $\mathrm{OH}$ & 0.00 & 0.00 & 0.00 \\
\hline Humid Continental - Warm Summer & Kansas City & MO & 0.00 & 0.00 & 0.00 \\
\hline Humid Continental - Warm Summer & Omaha & $\mathrm{NE}$ & 0.00 & 0.00 & 0.00 \\
\hline Humid Continental - Warm Summer & Philadelphia & PA & 0.00 & 0.00 & 0.00 \\
\hline Humid Southern & Atlanta & GA & 0.00 & 0.00 & 0.00 \\
\hline Humid Southern & Houston & TX & 0.00 & 0.00 & 0.00 \\
\hline Humid Southern & Memphis & $\mathrm{TN}$ & 0.00 & 0.00 & 0.00 \\
\hline Humid Southern & New Orleans & LA & 0.00 & 0.00 & 0.00 \\
\hline Humid Southern & San Antonio & TX & 0.06 & 0.34 & 2.02 \\
\hline Humid Southern & Raleigh & $\mathrm{NC}$ & 0.00 & 0.00 & 0.00 \\
\hline Humid Southern & Washington & $\mathrm{DC}$ & 0.00 & 0.00 & 0.00 \\
\hline Marine - West Coast & Olympia & WA & 0.02 & 0.08 & 0.48 \\
\hline Marine - West Coast & Portland & OR & 0.05 & 0.28 & 1.31 \\
\hline Marine - West Coast & Seattle & WA & 0.03 & 0.11 & 0.71 \\
\hline Mediterranean & Los Angeles & $\mathrm{CA}$ & 1.09 & 1.98 & 6.81 \\
\hline Mediterranean & Sacramento & $\mathrm{CA}$ & 1.60 & 4.11 & 8.70 \\
\hline Mediterranean & San Francisco & $\mathrm{CA}$ & 0.48 & 1.45 & 4.17 \\
\hline Semi-arid & Amarillo & $\mathrm{TX}$ & 0.06 & 0.29 & 2.65 \\
\hline Semi-arid & Boise & ID & 0.19 & 0.74 & 3.23 \\
\hline Semi-arid & Denver & $\mathrm{CO}$ & 0.00 & 0.18 & 1.66 \\
\hline Semi-arid & Rapid City & SD & 0.00 & 0.08 & 1.04 \\
\hline Semi-arid & Salt Lake City & UT & 0.45 & 1.71 & 5.29 \\
\hline Subarctic & Anchorage & $\mathrm{AK}$ & 0.00 & 0.02 & 0.20 \\
\hline Tropical & Honolulu & $\mathrm{HI}$ & 0.00 & 0.00 & 0.00 \\
\hline Tropical & Miami & $\mathrm{FL}$ & 0.00 & 0.00 & 0.14 \\
\hline
\end{tabular}




\subsection{Determine your Irrigation System Efficiency}

After determining your irrigation factor, estimate the efficiency of your irrigation system. System efficiency relates to how much irrigation water is actually being used by your turf or plants. Your system efficiency is based on the type of irrigation equipment installed as well as the maintenance and scheduling of the system. A perfect system, operating at $100 \%$ efficiency, would have no leaks, losses, or waste. But no system is $100 \%$ efficient -- water is lost from runoff, leaks, and evaporation for example. Efficiency can also be impacted by poor maintenance such as broken sprinkler heads or caused by scheduling problems such as watering during windy periods.

The type of irrigation equipment that is used to water the landscape has a big impact on system efficiency. For turf and landscape irrigation, there are two main types of equipment:

- Sprinkler systems: water delivered across a wide area through sprinkler heads such as pop-up and rotor heads

- Micro irrigation: water delivered at lower pressures directly to the root zone of the plant via drip or micro-spray equipment

Sprinkler systems tend to have a lower equipment efficiency ranging between $50 \%$ to $70 \%$ where micro irrigation have less losses with efficiency ratings between $70 \%$ and $90 \%$. [Alliance for Water Efficiency 2009]

To determine your system efficiency, choose the efficiency rating from the list below that best matches the characteristics of your system [Alliance for Water Efficiency 2009]:

- Low Efficiency - 50\%: sprinkler type systems that are aging with poor maintenance and lack of proper scheduling

- Medium Efficiency - 65\%: sprinkler type systems that have regular maintenance and proper scheduling

- High Efficiency - 85\%: micro irrigation systems that have regular maintenance and proper scheduling

If you feel your system does not fall into one of these efficiency ratings, choose a number in between these values that best matches the scenario at your location. 


\subsection{Calculate your Total Annual Irrigation}

The final step is to calculate the total irrigation requirements of your turf or landscaped area. To do this, multiply the annual irrigation factor by the landscaped area (in square feet) and divide by the system efficiency. This is represented in the following formula ${ }^{3}$ :

Annual Landscape Water Use (gallons per year)

$$
=\frac{\text { Annual Irrigation Factor }\left(\frac{g a l}{\text { sqft }-y r}\right) \times \text { Irrigation Area (sqft) }}{\text { Irrigation System Efficiency }}
$$

\section{Examples}

Here are two examples to illustrate this process to estimate annual irrigation of turfgrass and landscaped areas:

\section{Turfgrass Example}

A Federal facility located in Pittsburgh, PA has an 18-hole golf course with turfgrass that is combination of Kentucky bluegrass and fescue, covering 100 acres of turf. The golf course is supplied from an on-site non-potable well and therefore falls into the category of industrial, landscaping, and agricultural water use -- a baseline for FY 2010 is required per EO 13514. The well is not metered. The irrigation system and controls are fairly old and are in disrepair. A contractor manages the turf at the golf course and does not have any contractual obligation for maintaining an efficient system.

To estimate the amount of irrigation applied to this landscape using the method in this report, here are the steps to take to:

1. Find the best match for your location: The best match to Pittsburgh's climate is Philadelphia. Pittsburgh is located in the humid continental part of the US with warmer summers (as shown in Figure 1). The three cities that may have similar climate and irrigation requirement to Pittsburgh are Philadelphia, PA, Cincinnati, $\mathrm{OH}$, and Washington DC. To figure out the best matching city, a comparison is made of peak $\mathrm{ET}_{0}$ and rainfall data to Pittsburgh. The peak $\mathrm{ET}_{\mathrm{o}}$ and rainfall data for Pittsburgh is 5.70 and 3.59 inches per month respectively ${ }^{4}$. Comparing Pittsburgh data to the values in Table 1 for Philadelphia, Cincinnati, and Washington DC show that Philadelphia's peak ET。 and rainfall values are the closest to Pittsburgh's values ( 6.25 and 3.43 , respectively).

\footnotetext{
${ }^{3}$ Note because several estimates are required to use this formula, there is a wide range of possible answers that can be developed, which may result in a low overall accuracy. So this method should be used as a starting place to develop an initial baseline and should not be considered a measurement of actual water use.

${ }^{4}$ Peak $\mathrm{ET}_{\mathrm{o}}$ and rainfall data was obtained through the WaterSense Water Budget Data Finder Website: http://www.epa.gov/watersense/nhspecs/wb data finder.html
} 
2. Identify the turfgrass type: The turfgrass type for this location is cool season turf, which is identified in Table 2 of the report.

3. Estimate square footage of turf area: The total square footage of the golf course is $4,356,000$ sqft ( 1 acre equals 43,560 sqft)

4. Select the appropriate annual irrigation factor: The annual irrigation factor appropriate for this example is found in Table 3 under the column titled "cool season turf" for Philadelphia: 3.31 gal/sqft/yr.

5. Determine the efficiency of your irrigation system: $A$ low system efficiency of $50 \%$ was chosen because the irrigation system and controls are old and are not maintained well.

Applying this information to the following formula yields the estimated annual irrigation requirements for this golf course:

$$
3.31 \frac{\text { gallons }}{\text { sqft }- \text { year }} \times 4,356,000 \text { sqft } \div 0.50=\mathbf{2 8 , 8 3 6 , 7 2 0} \frac{\text { gallons }}{\text { year }}
$$

\section{Landscaped Area Example}

A Federal facility located in Colorado Springs, $\mathrm{CO}$ has a landscape area around a building that is irrigated with non-potable water. This irrigation is required to be included in the industrial, landscaping, and agricultural water use FY 2010 baseline. The landscaped area is a mixture of shrubs and perennials that are not native to the Colorado Springs area and have moderate water requirements. The landscape area is located near a building and receives southern exposure and is irrigated with pop-up style sprinkler heads. Grounds maintenance personnel calculated the area to be 10,500 square feet by manually measuring the border of the landscape. The system is maintained moderately well with well trained grounds maintenance personnel that are mindful to proper scheduling.

Here are the steps to take to determine the annual irrigation requirement for this area:

6. Find the best match for your location: The best match to Colorado Springs' climate is Laramie, WY. Colorado Springs is located on the border of the alpine and semi-arid climate zone (see Figure 1 for climate zone map). The three nearest cities to Colorado Springs shown on the climate map are Denver, CO, Santa Fe, NM and Laramie, WY. To figure out the best matching city, a comparison is made of peak $\mathrm{ET}_{\mathrm{o}}$ and rainfall data to Colorado Springs. The peak $\mathrm{ET}_{\mathrm{o}}$ and rainfall data for Colorado Springs is 7.45 and 1.73 inches per month respectively ${ }^{5}$. Comparing Colorado Springs data to the values in Table 1 for Denver, Santa Fe, and Laramie show that Laramie has the closest match of peak $\mathrm{ET}_{\mathrm{o}}$ and rainfall values of 7.44 and 1.33 , respectively.

\footnotetext{
${ }^{5}$ Peak $\mathrm{ET}_{\mathrm{o}}$ and rainfall data was obtained through the WaterSense Water Budget Data Finder Website: http://www.epa.gov/watersense/nhspecs/wb data finder.html
} 
7. Identify the landscape type: The landscape type is moderate water use with average density and intense exposure because it is located next to a building with southern exposure.

8. Estimate square footage of landscaped area: 10,500 sqft

9. Select the appropriate annual irrigation factor: Table 5 is the appropriate table for this landscape because the plants have moderate water requirements. Because the landscaped area has an average density and intense exposure, the appropriate factor is a value between Laramie's average density-open microclimate and high density-intense exposure annual irrigation factor. The mid-point between these two factors is 9.3, which was used for this landscape.

10. Determine the efficiency of your irrigation system: A medium system efficiency of $65 \%$ was chosen because pop-up sprinkler heads typically are moderately efficient and the system is fairly well maintained with good scheduling.

Applying this information to the following formula yields the estimated annual irrigation requirements for this landscaped area:

$$
9.3 \frac{\text { gallons }}{\text { sqft }- \text { year }} \times 10,500 \text { sqft } \div 0.65=\mathbf{1 5 0 , 2 3 1} \frac{\text { gallons }}{\text { year }}
$$




\subsection{Option 2: Estimating Landscaping Water Use Using the Irrigation Audit Method}

Estimating landscaping water use through the irrigation audit method requires the physical measurement of irrigation water applied to the landscape.

To use this method, you will be required to follow five steps:

1. Perform an irrigation audit

2. Calculate the precipitation rate of your equipment

3. Estimate annual runtime of your equipment

4. Estimate total area of your landscape

5. Calculate total annual irrigation

\subsection{Perform an Irrigation Audit}

An irrigation audit requires specific procedures to accurately estimate how much water is being consumed by your equipment. It is suggested that the Recommended Audit Guidelines produced by the Irrigation Association are followed when performing an irrigation audit ${ }^{6}$.[Irrigation Association 2009] The Irrigation Association has developed standard protocols for irrigation audits and also provides irrigation auditor certification training. The basic procedures outlined in these guidelines include the following steps:

- Obtain catchment devices, called "catch cans", which will be used to measure water from the system. (Irrigation audit catch cans can be purchased through internet sources. Pre-calibrated plastic rain gauges can also be used.)

- Measure the area of the "throat" of the catch can in square inches. The throat is the opening of the catch can.

- Perform a pre-inspection audit, testing for basic operational performance of the system and identifying problems such as broken heads. Make necessary repairs and adjustments.

- Place catch cans in a uniform pattern on the landscape area. Follow the Irrigation Association guidelines that specify spacing requirements for different types of sprinkler system equipment.

- Run the irrigation system over a given period of time - note the time period (typically done in 15 minute intervals).

- Test the system under normal operating conditions and with minimum wind (less than 5 miles per hour).

- Measure the volume of water in each catch can (typically measured in milliliters).

\footnotetext{
${ }^{6}$ The Recommended Audit Guidelines produced by the Irrigation Association is available at: www.irrigation.org/certification/pdf/AuditGuidelines final.pdf
} 


\subsection{Calculate your Precipitation Rate}

The basic goal of an irrigation audit is to determine your irrigation equipment's precipitation rate. The precipitation rate is the amount of water that is delivered to your landscape area over a given period of time, provided in inches per hour. The method described in this section only applies to sprinkler systems and not drip irrigation. Also, this method is best used for irrigation systems where the sprinkler heads provide similar precipitation rates. For example, if a landscape area has a mixture of rotor and pop up spray heads, estimating the precipitation rate of the system using an irrigation audit will not reflect the actual water consumption. Precipitation rates vary between different types of sprinkler heads ranging between 1.0 to 2.5 inches per hour for pop-up spray heads and 0.1 to 1.5 inches per hour for rotor type heads ${ }^{7}$. [Alliance for Water Efficiency 2009]

The precipitation rate can be calculated using the following formula:

$$
\begin{aligned}
& \text { Precipitation Rate }\left(\frac{\text { inches }}{\text { hour }}\right) \\
& =\frac{\text { Total Volume of Catch Cans (milliliters) } \times 3.66}{\text { Test Runtime (minutes) } \times \text { Throat Area of Catch Can (square inches) }}
\end{aligned}
$$

The factor 3.66 converts water volume of milliliters to cubic inches and runtime minutes to hours.

\subsection{Estimate your Annual Runtime}

Along with the precipitation rate, you also need to know the annual runtime of your system to estimate the annual landscape water use. The annual runtime of your system can be estimated by understanding your monthly or weekly irrigation schedule. Take the number of hours your system runs each week or month and multiply this number by the number of weeks or months your irrigation system operates throughout the year. (Note, many areas of the U.S. do not require irrigation during the cooler times of the year, so make sure to account for only the irrigation season of your landscape.) For example, if a system operates from April through September for 12 hours each month, then the annual runtime of the system is 72 hours.

\subsection{Estimate Square Footage of the Irrigated Area}

The other parameter that is required for estimating the annual landscape water use using the irrigation audit method is the total landscape area in square feet. Find information on this procedure that is described in section 2.4 titled Estimate Square Footage of the Irrigated Area.

\footnotetext{
${ }^{7}$ A good resource to get basic information on irrigation equipment, go to the Alliance for Water Efficiency website at: http://allianceforwaterefficiency.org/Irrigation System Heads Introduction.aspx
} 


\subsection{Calculate your Total Annual Irrigation}

To calculate the total annual landscape water use, utilize this formula:

$$
\begin{aligned}
& \text { Annual Landscape Water Use (gallons per year) } \\
& \qquad \begin{array}{l}
=\text { Precipitation Rate }\left(\frac{\text { inches }}{\text { hour }}\right) \times \text { Annual Runtime }\left(\frac{\text { hours }}{\text { year }}\right) \\
\times \text { Landscape Area }(\text { sqft }) \times 0.6233
\end{array}
\end{aligned}
$$

Note, the factor of 0.6233 converts volume of water to gallons from 1 square foot and 1 inch deep.

An irrigation audit will not only provide the precipitation rate of your system, but it can also provide the overall effectiveness of your system. A proper irrigation audit investigates how well the irrigation system is watering your landscape and can identify problem areas so repairs and adjustments can be made. If you choose the irrigation audit method, consider contracting a certified irrigation auditor or a WaterSense irrigation partner. Hiring a trained professional will ensure that the recommended Irrigation Association guidelines are followed appropriately and that you gain beneficial information on your irrigation system. To get more information on the Irrigation Association, go to:

http://www.irrigation.org And to get further information on how to locate a WaterSense irrigation partners, go to: http://www.epa.gov/watersense/meet our partners.html

Also, some state and local organizations may offer free irrigation audits as part of water conservation programs. Check with your water provider to see if these services may be available in your area. You may want to start your search through the EPA WaterSense program's website that provides a portal to access information on water efficiency rebates across the US at:

http://www.epa.gov/watersense/rebate finder saving money water.html 


\subsection{Subsequent Reporting Years}

Now that you've estimated your baseline for unmetered landscape water use, how will you document changes in water use for subsequent reporting years? The best approach is to install meters on these applications. This will offer you a way to check your baseline estimate and also accurately report any consumption changes in future years. If metering is not practical, you can use this document to report changes in water use by utilizing these same methodologies. This will not be entirely accurate, but it can provide you a methodology to estimate changes in irrigation. The following list provides some scenarios for estimating future changes in water use for unmetered landscape irrigation using either the ET method or irrigation audit method:

Evapotranspiration Method:

- If turf or landscape plants have been replaced with new species, choose a new annual irrigation factor that reflects the new landscape type and apply this factor to the annual landscape water use formula.

- If the operating efficiency has changed due to better scheduling or maintenance of the irrigation equipment, select a higher efficiency rating and apply to the annual landscape water use formula.

Irrigation Audit Method:

- If operating runtime changes, apply the new runtime to the annual landscape water use formula

- If the irrigation equipment has been repaired, perform another irrigation audit to estimate a new precipitation rate and apply to the given formulas. 


\subsection{Glossary}

Annual Irrigation Factor: This factor represents supplemental water requirements for turf or landscaped areas in gallons per square feet per year. The supplemental irrigation represents the amount of water needed during a typical growing season that is not satisfied by precipitation.

Effective Precipitation (EP): Effective precipitation is defined in this document as the amount of precipitation that is absorbed and stored in the soil, available for plants.

Evapotranspiration (ET): ET represents the loss of water from the Earth's surface through the combined processes of evaporation (from soil and plant surfaces) and plant transpiration (i.e., internal evaporation). [Irrigation Association 2001]

Irrigation System Efficiency: This term represents the percentage of beneficial irrigated water that reaches the turf or landscaped plants. For example, a system efficiency of $50 \%$ equates to half of the water applied to the landscape area reaches the plants while the other half of the irrigated water is wasted through inefficiencies such as runoff, broken sprinkler heads, and improper scheduling.

Landscape Water Consumption: This term is defined as the controlled application of water to outdoor spaces that have been designed to achieve socio-behavioral, environmental, and/or aesthetic outcomes to supplement water requirements not satisfied by rainfall. Examples of landscaping water consumption include (but are not limited to) irrigation of turf or landscaped beds and recreational fields.

Precipitation Rate: Precipitation rate is the amount of water that is applied to landscaped areas over a specific length of time through irrigation equipment measured typically in inches per hour.

Reference Evapotranspiration $\left(\mathrm{ET}_{\mathrm{o}}\right.$ ): The reference ET rate provides the total amount of water needed to grow high water consuming alfalfa grass during a specific time frame and location under conditions of that area (including variables such as humidity, temperature, and wind speed). $\mathrm{ET}_{0}$ does not include rainfall received in that area. This term specifically is the amount of water that evaporates from 4- to 7inch tall alfalfa growing in an open-field condition over a given time frame under specific conditions for a particular location. The units of $\mathrm{ET}_{\mathrm{o}}$ are typically provided in inches. [California Department of Water Resources 2000] 


\subsection{Resources}

The following links provide resources for researching water efficient strategies for landscaping and irrigation.

Alliance for Water Efficiency Resource Library on Landscape, Irrigation, and Outdoor Water Use: http://allianceforwaterefficiency.org/Landscape and Irrigation Library Content Listing.aspx

Irrigation Association - Smart Water Applications Technologies (SWAT):

http://www.irrigation.org/SWAT/Industry/

WaterSense Water Budget Tool: http://www.epa.gov/watersense/nhspecs/water budget tool.html

Watersmart Guidebook: A Water-Use Efficiency Plan Review Guide for New Businesses by East Bay Municipal Utility District:

http://www.allianceforwaterefficiency.org/WaterSmart Guidebook for Businesses.aspx

University of California Cooperative Extension Center for Landscape and Urban Horticulture: http://groups.ucanr.org/CLUH/Landscape Irrigation Management and Conservation/ 


\subsection{References}

Alliance for Water Efficiency. 2009. Irrigation Equipment Introduction Website, Chicago, IL provided typical efficiency of irrigation systems:

http://allianceforwaterefficiency.org/Irrigation Equipment Introduction.aspx . Accessed July 2010.

California Department of Water Resources. August 2000. A Guide to Estimating Irrigation Water Needs of Landscape Planting in California - The Landscape Coefficient Method and WUCOLS III, University of California Cooperative Extension, Sacramento, CA - provided basic methodology for calculating annual irrigation factors: www.water.ca.gov/wateruseefficiency/docs/wucols00.pdf. Accessed July 2010.

Irrigation Association. December 2001. The ASCE Standardized Reference Evapotranspiration Equation, Falls Church, VA - provided definition of evapotranspiration:

http://www.irrigation.org/defaultcontent. aspx?id=844\&terms=ASCE+Standardized+Reference+Evap otranspiration. Accessed July 2010.

Irrigation Association. September 2009. Recommended Audit Guidelines, Falls Church, VA provided steps for irrigation auditing practices:

http://www.irrigation.org/defaultcontent.aspx?id=842\&terms=Audit+guidelines. Accessed July 2010.

University of Florida, Irrigation Research, Southwest Florida Water Management District. 2009.

Turfgrass Crop Coefficients Website, Institute of Food and Agricultural Sciences Extension, Gainesville, FL - provided turfgrass crop coefficients:

http://irrigation.ifas.ufl.edu/turfgrass/turfgrass-crop-coefficient.shtml. Accessed July 2010.

U.S. Environmental Protection Agency. March 2010. Water Budget Tool Website, N.W. Washington, D.C. - provided reference evapotranspiration and precipitation data:

http://www.epa.gov/watersense/nhspecs/wb data finder.html. Accessed July 2010.

ZenTech. 2010. Climate Guide Website, Japan - provided the climate map:

http://www2m.biglobe.ne.jp/\%257eZenTech/English/Climate/USA/index.htm. Accessed July 2010. 


\section{Appendix}

\section{Calculations for the Annual Irrigation Factor Tables}





\section{Appendix -- Calculations for the Annual Irrigation Factor Tables}

Information provided in the Appendix documents the approach taken to calculate the annual irrigation factors. It is not necessary to read the Appendix to use the process outlined in the main body of the document. But, if the reader wishes to calculate the annual irrigation factor using precise ET data of a given location instead of utilizing the annual irrigation factors provided Tables $3-6$ in the main body of the report, then the Appendix can serve as a model to prepare the necessary calculations.

The type of data needed to calculate the annual irrigation factors are the following:

- Reference Evapotranspiration

- Turfgrass Evapotranspiration (also called crop evapotranspiration)

- Landscape Evapotranspiration

- Turfgrass and Landscape Coefficients

- Precipitation

The following section details these factors and equations used to develop the annual irrigation factor.

\section{Evapotranspiration}

The evapotranspiration method was used to develop the data to calculate the annual irrigation factors. This approach utilizes information on actual water requirements for specific landscape types based on the evaporation and transpiration of the plants in the landscape.

\section{Turfgrass Evapotranspiration}

The general equation used to calculate water requirements for turfgrass is as follows [6]:

$$
E T_{c}=K_{c} \times E T_{o}
$$

Where:

$$
\begin{aligned}
& \mathrm{ET}_{\mathrm{c}}=\text { Turfgrass Evapotranspiration (also known as crop evapotranspiration) } \\
& \mathrm{K}_{\mathrm{c}}=\text { Turfgrass Coefficient (also known as crop coefficient) } \\
& \mathrm{ET}_{\mathrm{o}}=\text { Reference Evapotranspiration }
\end{aligned}
$$

The turfgrass evapotranspiration is amount of water (typically in inches over a given time period) needed to maintain healthy turf for a given location. This value is adjusted based on a "reference crop". The reference crop is alfalfa, which is a high water-consuming grass. In other words, water required for all turf types whether it is Kentucky bluegrass or Bermuda grass is compared to the water needs of alfalfa. So, the reference evapotranspiration is the total amount of water needed to grow alfalfa grass during a specific time frame and location under typical regional conditions for that area (including variables such as humidity, temperature, and wind speed). 
The turfgrass coefficient indicates the relative amount of water needed for the landscape compared to the reference crop (which has a $K_{c}$ of 1 ). This term is also referred to as crop coefficient and represents the fraction of water lost from different species of turfgrass relative to the reference evapotranspiration. Cool season grasses, such as fescue, have a $\mathrm{K}_{\mathrm{c}}$ of 0.8 , while warm season grasses have a $\mathrm{K}_{\mathrm{c}}$ of 0.6 . This means that cool season grasses typically require about $80 \%$ of the water of alfalfa to retain a healthy state while warm season grasses such as Bermuda and zoysiagrass need about $60 \%$ of the water. [California Department of Water Resources 2000] Note the turfgrass evapotranspiration does not include precipitation received by the location.

\section{Landscape Evapotranspiration}

The general equation used to calculate water requirements of landscaped areas which includes a combination of plants such as shrubs, flowers, and trees is as follows [California Department of Water Resources 2000]:

$$
E T_{L}=K_{L} \times E T_{o}
$$

Where:

$$
\begin{aligned}
& E T_{L}=\text { Landscape Evapotranspiration } \\
& K_{L}=\text { Landscape Coefficient } \\
& E T_{O}=\text { Reference Evapotranspiration }
\end{aligned}
$$

Similar to the description above for turfgrass, landscape evapotranspiration calculates the amount of water needed to maintain a healthy landscape. The landscape coefficient reflects the fraction of water needed to maintain the health of a given landscape relative to the amount of water needed for the reference crop of alfalfa. The landscape coefficient is based on three factors: 1) type of species, 2) density of plants in the landscape, and 3) the microclimate of the landscape (e.g. protected vs. exposed). Each of these factors are multiplied together to determine the overall landscape coefficient. Here is the equation for landscape coefficient [California Department of Water Resources 2000]:

$$
K_{L}=k_{S} \times k_{d} \times k_{m c}
$$

Where:

$$
\begin{aligned}
& \mathrm{k}_{\mathrm{s}}=\text { Species Factor } \\
& \mathrm{k}_{\mathrm{d}}=\text { Density Factor } \\
& \mathrm{k}_{\mathrm{mc}}=\text { Microclimate Factor }
\end{aligned}
$$

The factors are explained below:

\section{Species Factor $\left(\boldsymbol{k}_{s}\right)$}

The species factor is defined by the water needs of the plants in the landscape for the given location. The following species factors can be applied to three general landscape types:

- Low $\mathrm{k}_{\mathrm{s}}$ : Plants with minimal water needs have a low $\mathrm{k}_{\mathrm{s}}$ ranging between 0.1 and 0.3 
- Average $k_{s}$ : Plants with moderate water needs have an average $k_{s}$ of between 0.4 and 0.6

- High $\mathrm{k}_{\mathrm{s}}$ : Plants with elevated water requirements have a high $\mathrm{k}_{\mathrm{s}}$ of between 0.7 and 0.9.

Note, if there is a mixture of plants with differing water needs, the species factor is chosen for the plant type with the highest water requirement.

\section{Density Factor $\left(k_{d}\right)$}

The density factor determines how densely populated the plants are in the landscape. The following density factors can be applied to three general landscape types:

- Low $\mathrm{k}_{\mathrm{d}}$ : Immature and sparsely planted landscape have a low $\mathrm{k}_{\mathrm{d}}$ ranging between 0.5 and 0.9

- Average $k_{d}$ : Predominantly one vegetation type have an average $k_{d}$ of 1

- High $\mathrm{k}_{d}$ : Landscape with mixture of plant types with full coverage have a high $\mathrm{k}_{d}$ ranging between 1.1 and 1.3.

\section{Microclimate Factor $\left(\boldsymbol{k}_{m c}\right)$}

The microclimate factor takes into consideration the environment in which the landscape is planted. Factors determining $\mathrm{k}_{\mathrm{mc}}$ include effects of temperature, wind, and amount of sunlight. The following microclimate factors can be applied to three general landscape types:

- Low $\mathrm{k}_{\mathrm{mc}}$ : Areas shaded from sunlight and protected from wind and heat gain have a low $\mathrm{k}_{\mathrm{mc}}$ ranging between 0.5 and 0.9

- Average $\mathrm{k}_{\mathrm{mc}}$ : Landscape areas that are in an open flat field (the same as the reference conditions) have an average $k_{\mathrm{mc}}$ of 1

- High $\mathrm{k}_{\mathrm{mc}}$ : Landscape areas with intense exposure to the elements such as high heat gain or windy conditions have a high $\mathrm{k}_{\mathrm{mc}}$ ranging between 1.1 and 1.4 .

\section{Reference ET。 Rates and Precipitation Data}

The reference evapotranspiration ( $\mathrm{ET}_{\mathrm{o}}$ )and precipitation data used in this document was provided through the U.S. Environmental Protection Agency's WaterSense program. WaterSense has developed a tool called the WaterSense Landscape Water Budget Tool (http://www.epa.gov/watersense/nhspecs/water budget tool.html). [U.S. Environmental Protection Agency 2010] This tool utilizes $\mathrm{ET}_{0}$ rates and precipitation developed by the International Water Management Institute (IWMI) Climate Atlas. The IWMI Climate Atlas utilizes 30 years of historical climate data. The data includes information by location on factors including precipitation, temperature, humidity levels, and evaporation rates to calculate the $\mathrm{ET}_{\mathrm{o}}$ for specific locations. 
WaterSense provided monthly $\mathrm{ET}_{\mathrm{o}}$ and precipitation data for specific locations which were included in the tables of this document. The growing season for each location was determined to be those months where reference evapotranspiration exceeded precipitation. Also, the effective precipitation was taken into account as well in the model which assumed that $85 \%$ of the precipitation that was received by the landscape area was absorbed by the soil and usable by the plants.

\section{Annual Irrigation Factor}

The annual irrigation factor provided in tables of this document represents the amount of water in gallons per square foot required to maintain a healthy landscaped or turf area over 1 year. The annual irrigation factor takes into account the growing season for the location and plant type as well as the amount of effective precipitation that is typically received in that area on a monthly basis. The following formula represents the annual irrigation factor:

$$
\begin{aligned}
& \text { Annual Irrigation Factor } \frac{\text { gallons }}{\text { sqft }- \text { year }} \\
& \qquad=\left[\sum \text { monthly ETc }-\sum \text { monthly precipitation } \times E P\right] \times C u
\end{aligned}
$$

Where:

Annual Irrigation Factor (gallons per square foot per year) = supplemental water required to maintain healthy landscape per square foot of landscaped area

$\sum \mathrm{ET}_{\mathrm{c}}=$ sum of monthly crop or landscape coefficients during the growing season for the specific location, in inches per month.

$\sum$ Rainfall $=$ sum of monthly historical rainfall received during the growing season for the specific location, in inches per month.

$E P=$ effective precipitation factor representing the amount of precipitation that is actually absorbed by the soil for plant growth

$\mathrm{C}_{\mathrm{u}}=$ conversion factor of 0.6233 to convert annual irrigation from inches to gallons

The annual irrigation factor represents the sum of monthly supplemental water requirements to maintain a healthy landscape or turf area, shown in the Tables 3 through 6 of the document. The user of the document then multiplies the annual irrigation factor by the landscape area (square feet) and divides by the system efficiency to calculate the estimated total irrigation needed for the year. 


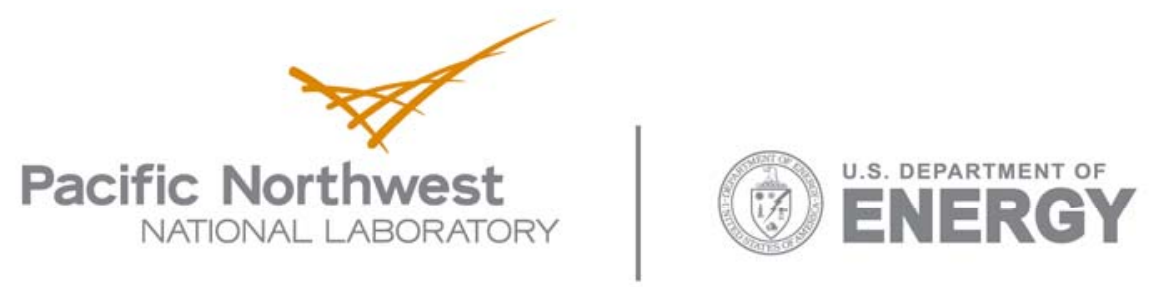

902 Battelle Boulevard

P.O. Box 999

Richland, WA 99352

1-888-375-PNNL (7665)

www.pnl.gov 